\title{
Migration of an upper trophic level predator, the salmon shark Lamna ditropis, between distant ecoregions
}

\author{
Kevin C. Weng ${ }^{1,3, *}$, David G. Foley ${ }^{2}$, James E. Ganong ${ }^{1}$, Christopher Perle ${ }^{1}$, \\ George L. Shillinger ${ }^{1}$, Barbara A. Block ${ }^{1}$ \\ ${ }^{1}$ Hopkins Marine Station, Stanford University, Pacific Grove, California 93950 USA \\ ${ }^{2}$ Environmental Research Division, NOAA Fisheries Service, Pacific Grove, California 93950, USA \\ ${ }^{3}$ Present address: School of Ocean and Earth Science and Technology, University of Hawaii at Manoa \\ Honolulu, Hawaii 96822, USA
}

\begin{abstract}
Knowledge of how animals move through heterogeneous environments is essential to understanding the ecological functions they fulfill in each habitat and their responses to environmental change. Upper trophic level organisms exert structural influences through the food web, so information on their range, migration and foraging strategy is necessary to understanding ecosystem function. Recent technological advances have enabled researchers to follow individual animals over seasonal and multi-year timescales, revealing long-distance migrations in a variety of taxa. We used satellite telemetry to monitor female salmon sharks Lamna ditropis and remote sensing to characterize their environment. Salmon sharks ranged throughout the entire eastern North Pacific Ocean during a seasonal migration cycle. During long-distance migrations, quantitative movement analyses of speed, path straightness and first passage time (FPT) revealed area-restricted search (ARS) behaviors in northern and southern regions, with transiting behaviors at mid-latitudes. Individuals migrating to a highly productive southern region displayed more ARS behaviors than those moving to a low productivity region. The combination of multi-year time-series of animal behavior with synoptic environmental data reveals factors influencing migration and indicates that different life history functions are fulfilled in each habitat.
\end{abstract}

KEY WORDS: Migration - Behavior - Habitat selection - Landscape ecology - Oceanography · Foraging behavior $\cdot$ Reproduction $\cdot$ Elasmobranch $\cdot$ Lamna ditropis

Resale or republication not permitted without written consent of the publisher

\section{INTRODUCTION}

To understand the life history and ecology of a species and ultimately to predict its response to environmental change, home range, movements and habitat selection must be known (Dingle 1996). Because of the ocean's scale and dynamics, we have limited understanding of its most wide-ranging inhabitants. The best known taxa are those that conduct key phases such as mating or parturition where they can be directly observed - on land in the cases of marine birds (Serventy 1967), turtles (Spotila 2004) and pinnipeds (Le Boeuf \&
Laws 1994), and in nearshore waters in the case of whales (Gilmore 1960). In wide-ranging pelagic fishes there are few opportunities to make direct observations (Sundstrom et al. 2001). For these species, we must make inferences based on the available data (Teo et al. 2007).

The oceans have strong regional differences in primary productivity (Longhurst 1998). Theory suggests that a predator in a patchy prey-field will spend more time and search more intensively in rich foraging areas than in sparse areas, a behavior termed area-restricted search (ARS) (Kareiva \& Odell 1987). ARS behavior 
has been used as a feeding proxy for a variety of marine vertebrates (Robinson et al. 2007), and studies combining both movement and feeding data have validated ARS in fish and bird species (Hill et al. 2000, Nolet \& Mooij 2002).

Like all proxies, the use of ARS behavior to indicate foraging is not perfect. Animals may move for reasons other than foraging (Dingle 1996), so ARS behavior could be foraging, mating, parturition or selection of environment. By combining measurements of both behavior and the environment we may gain clues to the ecology of organisms that cannot be directly observed (Pinaud \& Weimerskirch 2005). ARS can be measured with analyses of speed, turning and straightness, or with more complex analyses (Robinson et al. 2007). First passage time (FPT) is a useful indicator of ARS behavior (Fauchald \& Tveraa 2003) and is defined as the time an organism takes to cross a circle of a given radius. It is more robust to gaps in track records than speed or straightness.

Top-down processes can have structural impacts on ecosystems (Hunter \& Price 1992), so knowledge of upper trophic levels is essential to understanding ecosystem function. The salmon shark Lamna ditropis Hubbs et Follet, 1947 is an important component of the ecosystem due to its upper trophic level, abundance and high forage requirements due to its high metabolic rate (Nagasawa 1998, Bernal et al. 2005). An ecosystem model of Prince William Sound, Alaska, found that sharks had the second highest consumption of all top predator groups in the system, exceeding whales, birds, pinnipeds and most teleost groups including salmon (Okey \& Pauly 1999). Salmon sharks were responsible for over $60 \%$ of all shark consumption, making them one of the top consumers in the ecosystem.

The salmon shark is in the family Lamnidae, which occurs throughout the polar, temperate and tropical oceans (Hubbs \& Follett 1947, Goldman \& Musick 2008). Lamnid sharks are endothermic, a trait that may underlie their wide ambient temperature range, high performance swimming and trophic specializations on large, fast prey species (Bernal et al. 2005, Weng et al. 2005). Migration in salmon sharks has been described (Hulbert et al. 2005, Weng et al. 2005), and the present study explores the ecological functions underlying them. The questions addressed are the following: How do salmon sharks move throughout the eastern North Pacific, and are these movements consistent from year to year? Do the movements of salmon sharks correlate with regional differences in productivity across the eastern North Pacific? What life history functions appear to be fulfilled during the various phases of the migration cycle? What ecological advantages, if any, are conferred by the migratory life history of salmon sharks?

\section{MATERIALS AND METHODS}

Satellite telemetry. Sixty-eight female salmon sharks were monitored using satellite telemetry. Details of these sharks are given in Appendix 1, available in MEPS Supplementary material at www.int-res.com/articles/ suppl/m372p253_app.pdf. Thirty-eight individuals were included in the study of Weng et al. (2005). Sharks averaged $211 \pm 10 \mathrm{~cm}$ (mean $\pm \mathrm{SD}$ ) total length and were mature based on size at maturity data (Goldman \& Musick 2006). We captured sharks using hook and line in Prince William Sound, Alaska, during the summers of 2002 to 2005 and attached satellite tags (SPOT, Wildlife Computers) to their dorsal fins as described by Weng et al. (2005). The Argos tracking and environmental monitoring system (www.argos-system.org) classifies positions on a 7-point scale, from best to worst: 3, 2, 1, 0 , A, B and Z. Argos states that the root mean square (RMS) errors for its positions are: Class 3,>150 m; Class 2, 150-350 m; Class 1, 350-1000 m; Classes 0, A, B and Z, no estimates provided. Estimates for Classes 0, A and $B$ have been published in the literature, showing RMS error for the last position class (B) of approximately $8 \mathrm{~km}$ (Hays et al. 2001a), and up to about $50 \mathrm{~km}$ (White $\&$ Sjoberg 2002). This error scale, when compared to the scale of shark movement in the present study, did not seriously erode the measurement of animal behavior (Bradshaw et al. 2007).

Environmental data. Sea surface temperature (SST), chlorophyll a (chl a), primary productivity (PP), sea surface height deviation (SSH) and water depth were obtained for each space-time point in each track by referencing synoptic oceanographic datasets maintained by NOAA and AVISO. We queried data from the Oceanwatch Live Access Server (http://las.pfeg.noaa.gov/oceanWatch) using MatLab (The Mathworks) and ERDDAP (http:// coastwatch.pfel.noaa.gov/erddap). SST was blended from multiple sources to optimise coverage, comprising the Moderate Resolution Imaging Spectroradiometer (MODIS), Advanced Very High Resolution Radiometer (AVHRR), Imager, and the Advanced Microwave Scanning Radiometer (AMSR-E). Chl a was measured by MODIS and obtained as $8 \mathrm{~d}$ averages. PP was estimated from chl a measured by the Sea-viewing Wide Field-ofview Sensor (SeaWiFS) and SST measured using AVHRR (Behrenfeld \& Falkowski 1997). SSH was based on altimetry measurements from multiple spacecraft merged by AVISO. Water depth was determined using 2 min gridded global relief data (ETOPO2) from the National Geophysical Data Center (www.ngdc.noaa.gov/mgg/global/). To quantify environmental gradients such as fronts or mesoscale features, we calculated the standard deviation of SST, chl a, PP and SSH within 1 degree of the position.

Analysis. Tracks were filtered to remove positions with location Class Z, those on land, and those exceed- 
ing a speed of $1.75 \mathrm{~m} \mathrm{~s}^{-1}$ (Weng et al. 2005). We used a seasonal kernel density analysis (Worton 1989) of positions to quantify variation in habitat utilization using the Animal Movement Extension (Hooge \& Eichenlaub 1997) to ArcView version 3.3 (ESRI). Kernel density analysis assumes that the positions of animals are measured at event time intervals and that this interval does not change between individuals. This assumption is violated in Argos position data, because some individuals transmit many times per day, and others less frequently. To avoid the bias introduced by variation in sampling frequency, we regularized the filtered tracks to a frequency of $1 \mathrm{~d}$, up to $3 \mathrm{~d}$ intervals, using the piecewise cubic hermite interpolating polynomial, which had the highest accuracy of available methods (Tremblay et al. 2006).

To avoid bias introduced by short tracks, the kernel analysis used a subset of the data, comprising 34 individuals with median duration of $360 \mathrm{~d}$ (interquartile range 223 to $629 \mathrm{~d}$ ). The $50 \%$ probability contour shows major focal regions of sharks, the $80 \%$ contour minor focal regions, and the $95 \%$ contour regions of low utilization. The complete range of salmon sharks during each season was represented using the minimum convex polygon technique (Burt 1943) implemented in Hawth's Tools (Beyer 2004) for ArcInfo-9 (ESRI).

Derived measures of shark behavior were calculated from the filtered, interpolated position data comprising speed, straightness, distance from coast and FPT. We calculated speed using the distance function in the m_map toolkit (Pawlowicz 2006) and straightness by dividing the straight distance between 2 points $15 \mathrm{~d}$ apart by the actual path length between them (Batschelet 1981). Speed and straightness were not calculated where gaps exceeded $3 \mathrm{~d}$ in length. Gaps were calculated as the elapsed time between consecutive positions. The distance of each position from the North American mainland was calculated using the great circle method. We calculated FPT in MatLab using the method of Robinson et al. (2007). FPT was calculated across circles of varying radius and the radius having the greatest log variance in FPT was chosen as the spatial scale of the ARS behavior (Fauchald \& Tveraa 2003). FPT for this radius was then calculated along the track. ARS behavior, such as occurs during searching and foraging, was indicated by low speed, low straightness and high FPT, whereas the opposite values indi- cated that animals were transiting through a region. We estimated the starting and ending times of migration by defining migration as the state when $\mathrm{d} y / \mathrm{d} t>g$, where $y$ is latitude, $t$ is time and $g$ is a gradient threshold, which was set at $0.25^{\circ} \mathrm{d}^{-1}$.

We compared the movements of salmon sharks to the major ecoregions of the eastern North Pacific Ocean. The boundaries of oceanic regions move seasonally and with changes in oceanographic conditions so the allocation of a particular time-space position into an ecoregion was conducted dynamically, as follows (Fig. 1): the Subarctic Gyre was defined as waters $\leq 12^{\circ} \mathrm{C}$; the Transition Zone as 12.1 to $17.9^{\circ} \mathrm{C}$; and the Subtropical Gyre as $\geq 18^{\circ} \mathrm{C}$ (Longhurst 1998). Neritic regions were defined by their proximity to the coast, with the Coastal Alaska Downwelling Region being waters nearer than $150 \mathrm{~km}$ and north of $48^{\circ} \mathrm{N}$, and the California Current Upwelling Region south of $48^{\circ} \mathrm{N}$ and up to $1000 \mathrm{~km}$ from the coast at the southern margin, and $500 \mathrm{~km}$ from the coast at the northern margin (Longhurst 1998). Frequency histograms of salmon shark occupancy of different regions for each month of the year were normalized by the total number of observations in each month to remove bias caused by observational variation. Averages are presented as mean \pm standard deviation for normal distributions, and medi-

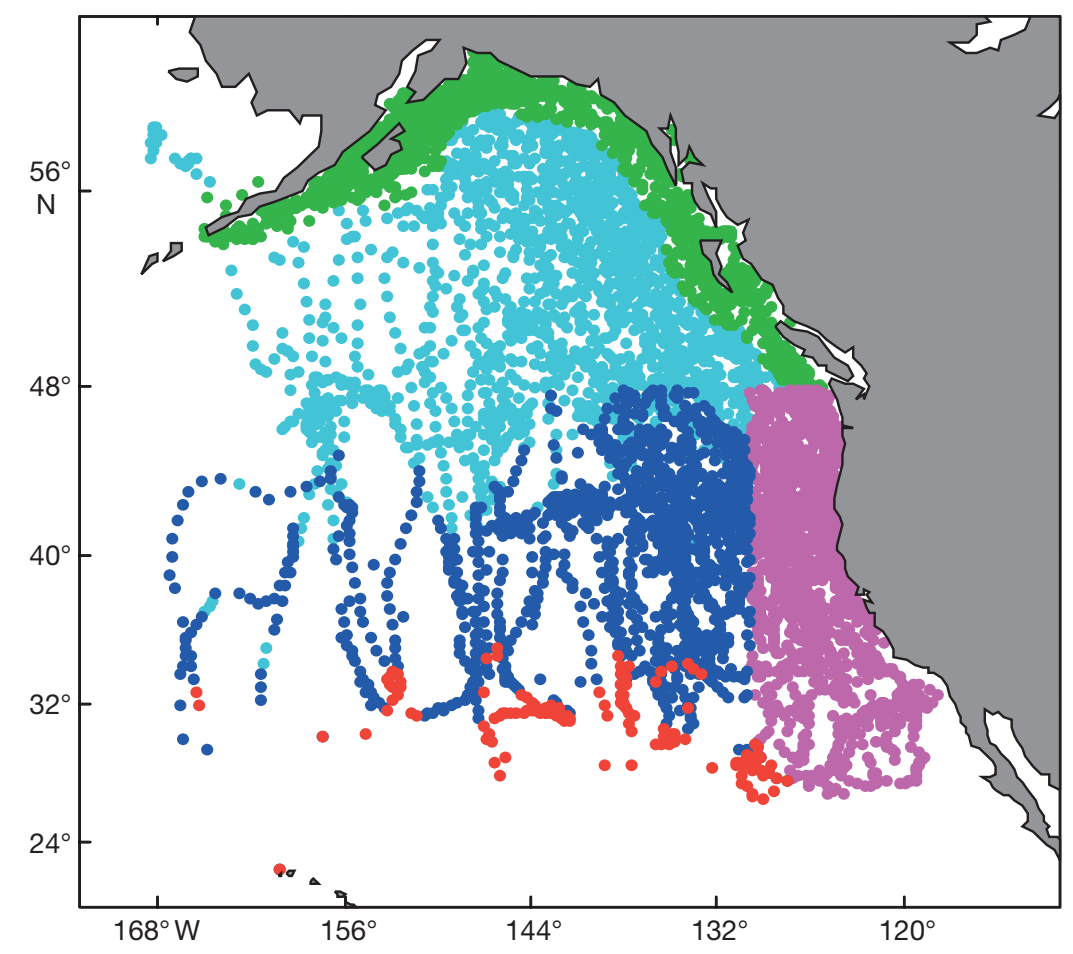

Fig. 1. Lamna ditropis. Occurrence of salmon sharks in the major ecoregions of the eastern North Pacific. Each point represents a daily position for one individual. Coastal Alaska Downwelling Region (green), California Current Upwelling Region (pink), Subarctic Gyre (cyan), Transition Zone (blue) and Subtropical Gyre (red) 
an, interquartile range $(\mathrm{Q} 1-\mathrm{Q} 3)$ for non-normal distributions. Summer, autumn, winter and spring refer to meteorological seasons in the northern hemisphere.

\section{RESULTS}

\section{Seasonal long-range migrations}

Salmon sharks migrated between subarctic foraging grounds and subtropical destinations from $168^{\circ} \mathrm{W}$ to the North American continental shelf. Details of individual shark behavior are given in Appendix 2 (www.int-res.com/articles/suppl/m372p253_app.pdf). Median speed was 33 (11 to 62; Q1-Q3) $\mathrm{km} \mathrm{d}^{-1}$, straightness (a dimensionless index where $1=$ a straight line and $0=$ an infinitely circuitous path) was 0.67 (0.37 to 0.88 ; Q1-Q3), and FPT was 7.9 (3.7 to 23.0; Q1-Q3) d. Median circle size in the FPT analysis was 90 (60 to 135; Q1-Q3) $\mathrm{km}$. Salmon showed fidelity to either the California Current or the Subtropical Gyre. For sharks tracked $>1$ yr (n =12), 3 consistently visited the California Current, 8 consistently visited the Subtropical Gyre, and 1 switched its destination. California Current migrations started earlier, were shorter in time and distance, more northerly, nearer the coast and in shallower water, as compared to sharks migrating to the Subtropical Gyre (Table 1).

ARS behavior - slow, sinuous swimming and high FPT-occurred in Coastal Alaska, in the California Current and to a lesser degree in the Subtropical Gyre, whereas the reverse behaviors, indicative of transiting, occurred in the Subarctic Gyre and Transition Zone (Fig. 2). Differences between regions were significant for all 3 behavioral indices (1-way ANOVA, p < 0.05; Fig. 3a-c).

Salmon sharks showed distinct focal and transiting regions - kernel densities peaked in coastal Alaska and California Current waters, with lower values in the Subtropical Gyre, Subarctic Gyre and Transition Zone (Fig. 4). During summer, salmon sharks were concentrated in coastal Alaska waters and the northern California Current region. During autumn, salmon sharks dispersed into the Subarctic Gyre and Transition Zone, and by winter had entered the Subtropical Gyre. In spring, the greatest dispersion and most southerly distribution occurred, with focal areas in both coastal Alaska and the California Current, and moderate utilization extending west through the Subtropical Gyre to waters north of Hawaii. The total area used by salmon sharks was large, but in all seasons most of the time was spent within small portions of the total range (Table 2).

Migration phenology was highly variable, with sharks leaving Coastal Alaska from 22 July to 8 March, with a median date of 8 January (22 November to 1 February; Q1-Q3). While migrating south speed varied from 25 to $103 \mathrm{~km} \mathrm{~d}^{-1}$, averaging 68 (73 to 79 ; Q1-Q3) $\mathrm{km} \mathrm{d}^{-1}$. Southern residency averaged 89 (51 to 129; Q1-Q3) d, and the start of northward migrations averaged 4 May (16 April to 90 June; Q1-Q3). Sharks remained in Coastal Alaska for 159 (120 to 238; Q1-Q3) d. Three individuals did not undertake a southern migration, remaining in Coastal Alaska waters through the winter and spring.

\section{Relation of movements to environment}

Across all sharks and regions, derived measures of behavior showed strong correlations (Spearman's rho 1/3) with chl a and PP, but weak correlations with SST and SSH (Table 3). High levels of chl a and PP, and high variation within these variables along oceanic fronts, were associated with slower and more sinuous

Table 1. Lamna ditropis. Differences between migrations destined for the California Current and Subtropical Gyre. Values are presented as 'median (Q1-Q3)' with the associated p-value from the nonparametric rank sum test

\begin{tabular}{|c|c|c|c|}
\hline & Subtropical Gyre $(\mathrm{n}=12)$ & California Current $(\mathrm{n}=19)$ & $\begin{array}{l}\text { Wilcoxon Rank } \\
\text { Sum (p) }\end{array}$ \\
\hline Start migrating south & 26 January (9 December-12 February) & 6 December (6 October-23 January) & 0.05 \\
\hline Arrive south & 4 March (4 February-21 March) & 17 January (28 October-28 February) & 0.01 \\
\hline Duration of migration (d) & $40(27-45)$ & $27(25-32)$ & 0.05 \\
\hline Distance $(\mathrm{km})$ & $2571(1770-2978)$ & $1975(1599-2548)$ & 0.15 \\
\hline Speed $\left(\mathrm{km} \mathrm{d}^{-1}\right)$ & $69(67-78)$ & $66(62-79)$ & 0.45 \\
\hline Residency in south (d) & $77(52-95)$ & $107(51-136)$ & 0.48 \\
\hline Start migrating north & 30 April (3 April-15 May) & 4 May (26 April-5 August) & 0.27 \\
\hline Duration of migration (d) & $34(23-42)$ & $28(20-46)$ & 0.62 \\
\hline Speed $\left(\mathrm{km} \mathrm{d}^{-1}\right)$ & $66(51-71)$ & $56(42-66)$ & 0.31 \\
\hline Arrive north & 6 June (27 May-14 June) & 29 June (17 May-3 September) & 0.32 \\
\hline Residency in north (d) & $182(137-224)$ & $159(82-239)$ & 0.59 \\
\hline Southernmost point $\left({ }^{\circ} \mathrm{N}\right)$ & $29(28-32)$ & $35(30-38)$ & 0.07 \\
\hline Distance to coast $(\mathrm{km})$ & $621(240-913)$ & $193(97-361)$ & 0 \\
\hline Median depth $(\mathrm{m})$ & $4012(2941-4649)$ & $2872(2186-3480)$ & 0.01 \\
\hline
\end{tabular}



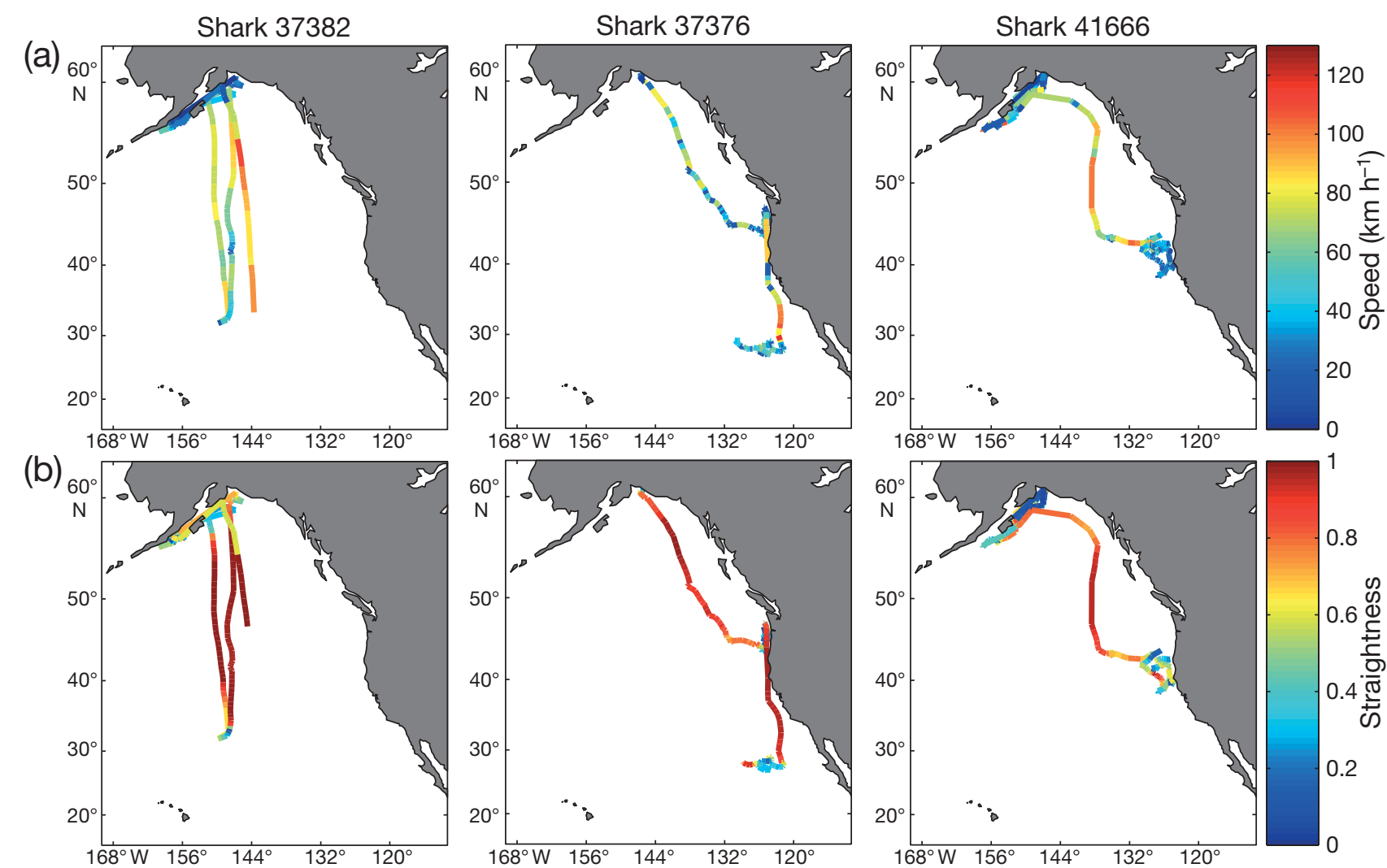

(c)
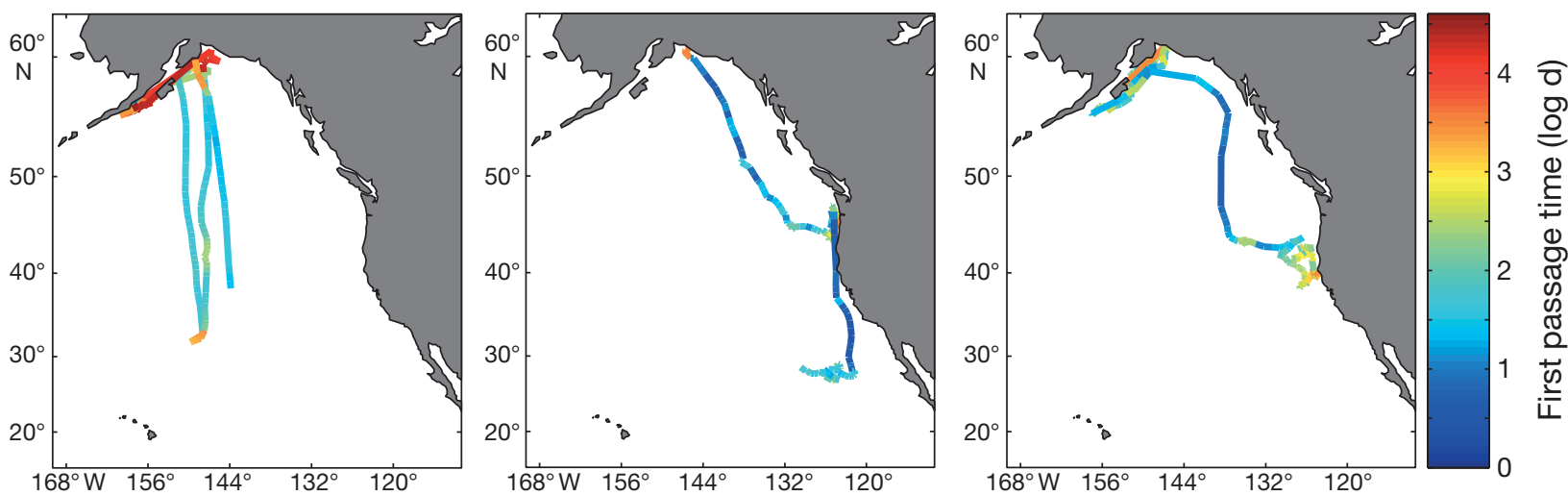

Fig. 2. Lamna ditropis. (a) Speed, (b) straightness, and (c) first passage time of 3 salmon sharks in the eastern North Pacific Ocean. Speed is in $\mathrm{km} \mathrm{d}^{-1}$, straightness in a dimensionless index $(1=$ straight line), and first passage time in $\log (\mathrm{d})$

swimming patterns and higher FPTs in salmon sharks (Table 3). Details of individual shark movements in relation to environmental variables are given in Appendix 3 (www.int-res.com/articles/suppl/m372p253 _app.pdf).

Comparisons between ecoregions showed that those used for transiting, the Subarctic Gyre and Transition Zone, had lower chl $a$ and PP than those where ARS behaviors occurred, with the exception of the Subtropical Gyre (Fig. 3d,e). Within each region the seasonal cycle of salmon shark utilization did not correlate with the seasonality of productivity.
Salmon sharks inhabited the Coastal Alaska Downwelling Region during all seasons with lowest utilization during spring (Fig. 5a). There was low correspondence between utilization of this region and environmental variables. The seasonality of SST, chl $a$ and PP in this region is extreme. Chl a concentration showed a spring peak prior to the largest influx of salmon sharks during summer, and then dropped to a low level in winter. The increase in salmon shark abundance during summer occurred during the summer increase in PP, but the high shark abundance continued through autumn and winter despite a precipitous decline in PP during those seasons. 
(a)

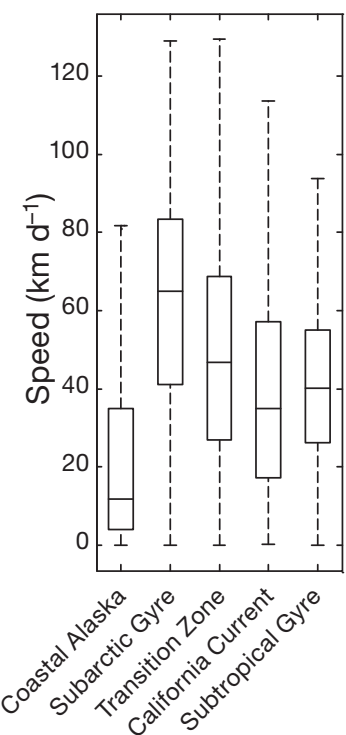

(b)

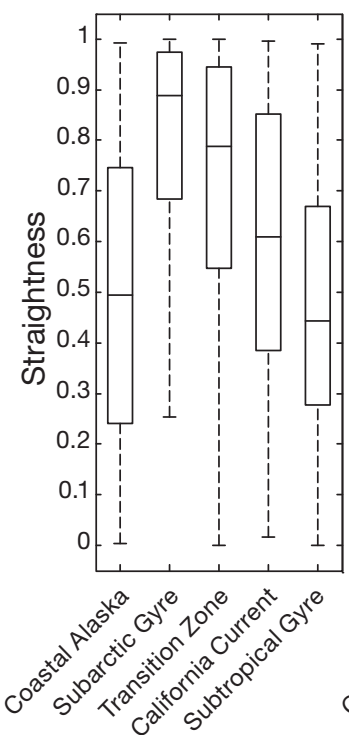

(c)

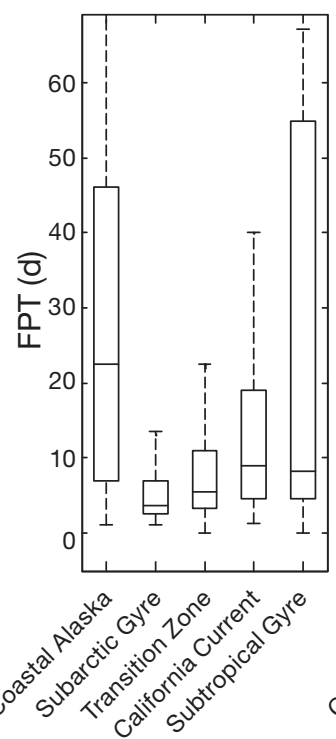

(d)

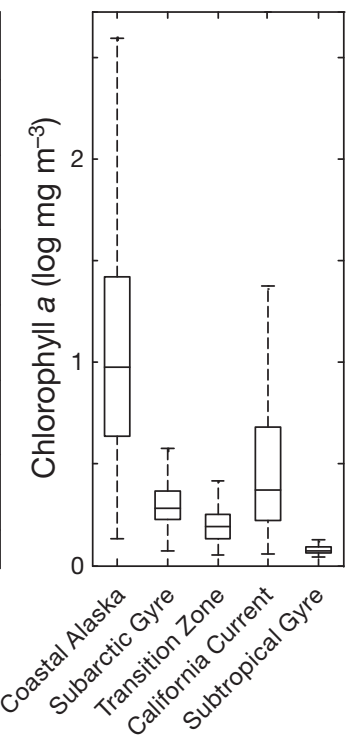

(e)

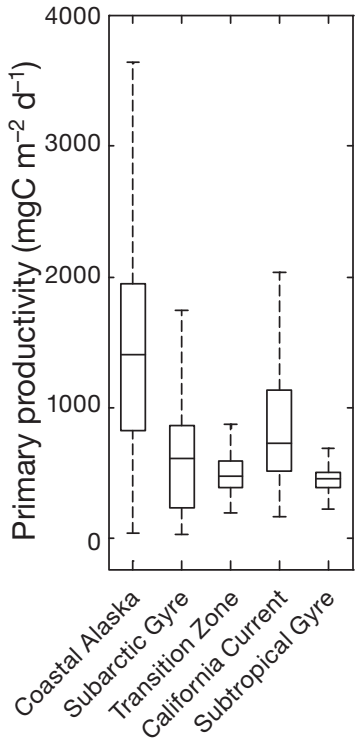

Fig. 3. Lamna ditropis. (a) Speed, (b) straightness, and (c) first passage time (FPT) of salmon sharks compared to (d) chlorophyll a concentration and (e) primary productivity in the major ecoregions of the eastern North Pacific Ocean. Boxplots: centerline, median; edges of box, 1st and 3rd quartiles; whiskers, data points within the range Q1 - 1.5(Q3 - Q1) to Q3 + 1.5(Q3 - Q1)
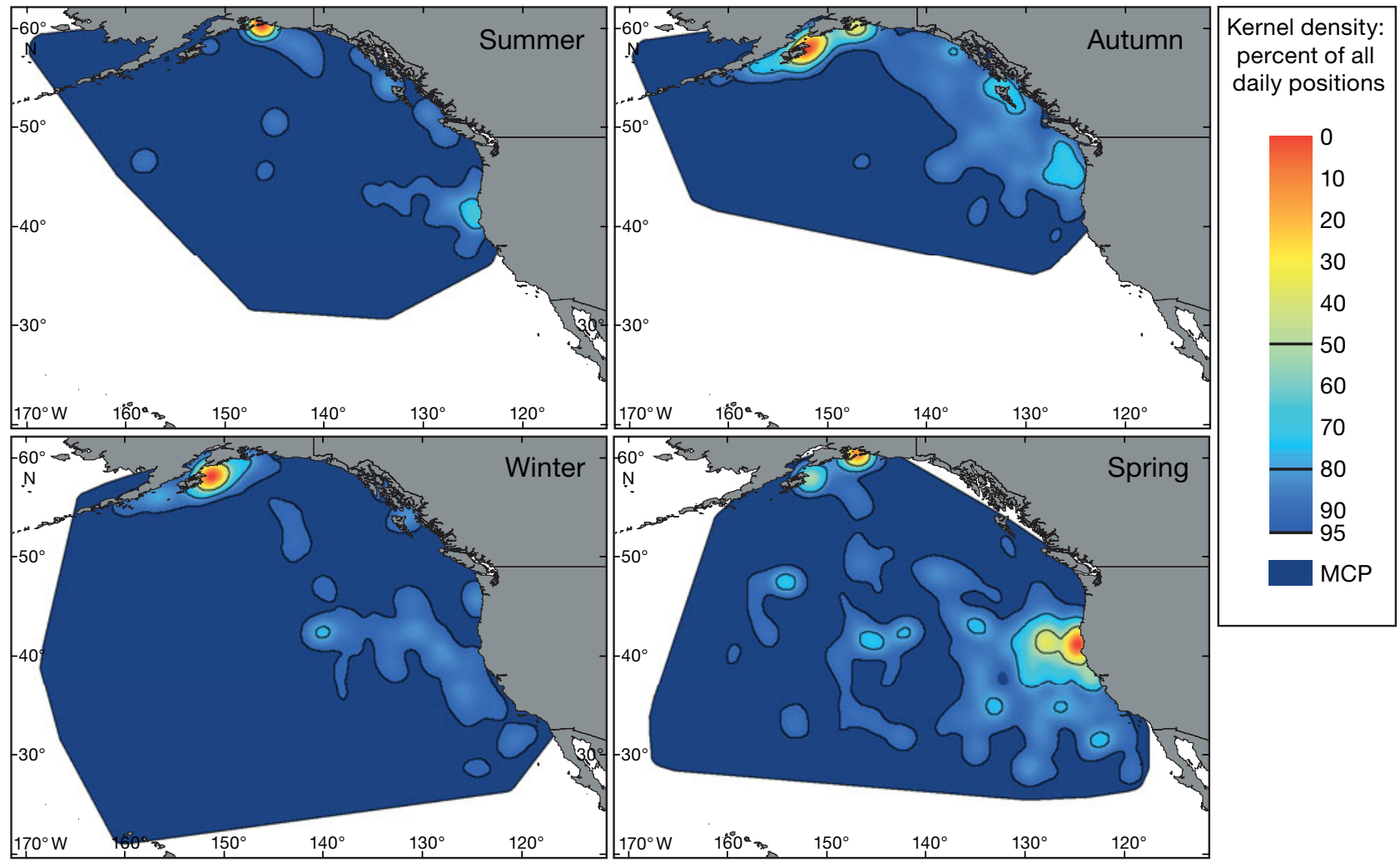

Fig. 4. Lamna ditropis. Kernel density of salmon sharks $(n=34)$ during 2002 to 2006. Kernel density shows the percentage of daily positions across all individuals and all years, within a given season. Color scale shows seasonal change in habitat utilization intensity of salmon sharks, while the complete range during each season is shown by the minimum convex polygon (MCP) 
Table 2. Lamna ditropis. Minimum convex polygon (MCP) areas of salmon shark range and focal areas by season

\begin{tabular}{|lrrr|}
\hline & $\begin{array}{c}\text { MCP } \\
\left(\mathrm{km}^{2}\right)\end{array}$ & $\begin{array}{c}50 \% \text { Contour } \\
\left(\mathrm{km}^{2}\right)\end{array}$ & Median latitude \\
\hline Summer & 6921391 & 128049 & $54^{\circ} \mathrm{N}\left(44-60^{\circ} \mathrm{N}\right)$ \\
Autumn & 5870645 & 237248 & $55^{\circ} \mathrm{N}\left(48-58^{\circ} \mathrm{N}\right)$ \\
Winter & 13112065 & 92643 & $50^{\circ} \mathrm{N}\left(41-57^{\circ} \mathrm{N}\right)$ \\
Spring & 10661010 & 278806 & $42^{\circ} \mathrm{N}\left(37-49^{\circ} \mathrm{N}\right)$ \\
\hline
\end{tabular}

Occupancy of the Subarctic Alaska Gyre peaked in autumn, coincident with the peak in chl $a$ and PP (Fig. 5b). The majority of occupancy occurred in the far eastern margin of the Gyre. Utilization of the Transition Zone peaked in spring, coincident with the spring bloom peaks in chl $a$ and $\mathrm{PP}$, with moderate utilization in winter and minimum levels during summer and autumn (Fig. 5c). The minimum utilization during autumn corresponded to the maximum levels of PP. In

Table 3. Lamna ditropis. Spearman's correlation coefficients between behavioral and environmental variables. FPT: first passage time; chl a: chlorophyll a: PP: primary productivity; SST: sea surface temperature; SSH: sea surface height deviation; SD: standard deviation

\begin{tabular}{|lrrrrrrrl|}
\hline & Chl a & SD_Chl $a$ & PP & SD_PP & SST & SD_SST & SSH & SD_SSH \\
\hline Speed & -0.43 & -0.42 & -0.38 & -0.38 & 0.13 & -0.22 & 0.05 & 0 \\
Straightness & -0.29 & -0.32 & -0.38 & -0.26 & 0.1 & -0.16 & 0.03 & 0.1 \\
FPT & 0.38 & 0.39 & 0.33 & 0.33 & -0.05 & 0.19 & -0.03 & 0.05 \\
\hline
\end{tabular}

the California Current Upwelling Region utilization was highest in the spring, corresponding to a peak in chl a concentration, but lowest in the summer and autumn when PP is highest (Fig. 5d). The Subtropical Gyre received the greatest utilization in winter and spring with very little usage during summer and autumn, and did not correspond with the seasonality of productivity (Fig. 5e).

\section{DISCUSSION}

\section{Long-range seasonal migration}

The long-distance migrations of many organisms occur because they have specific requirements for breeding and parturition, in areas that are distant from their foraging grounds (Dingle 1996). The ability to move rapidly across large oceanic regions allows salmon sharks to optimise their foraging across ocean basin scales, alternating between the 2 most productive ecoregions of the eastern North Pacific - coastal Alaska and the California Current. Variability in the timing, routing and destination of migration between individual sharks was large, indicating that the species probably does not undertake coordinated group migrations.

Pacific bluefin tuna Thunnus orientalis spawned near Japan and Taiwan (a) Coastal Alaska Downwelling

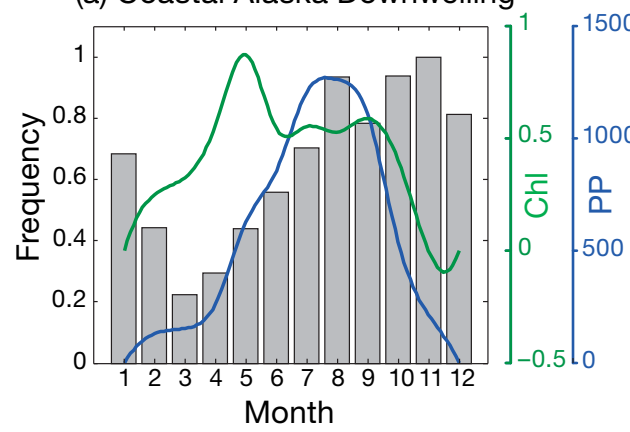

(d) California Current Upwelling

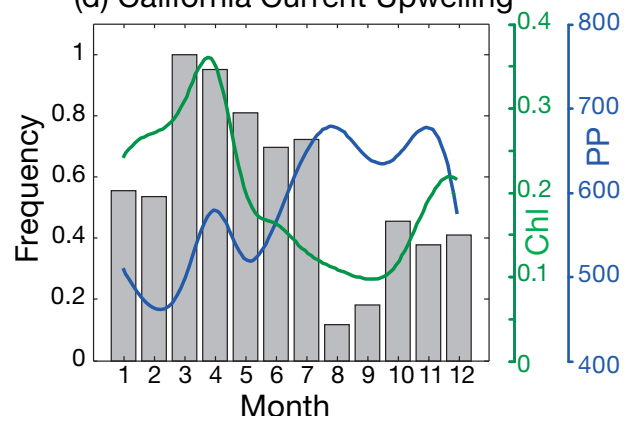

(b) Subarctic Alaska Gyre

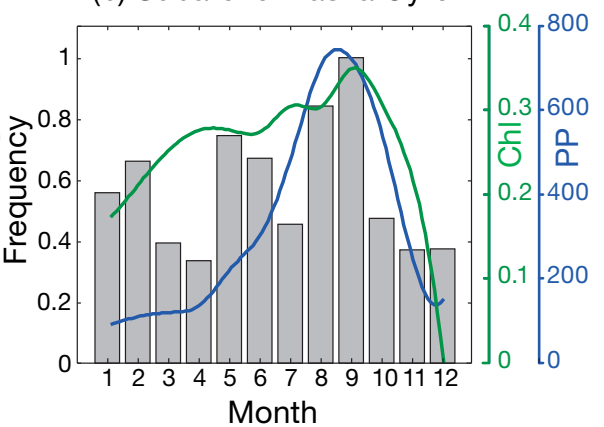

(e) Subtropical Gyre

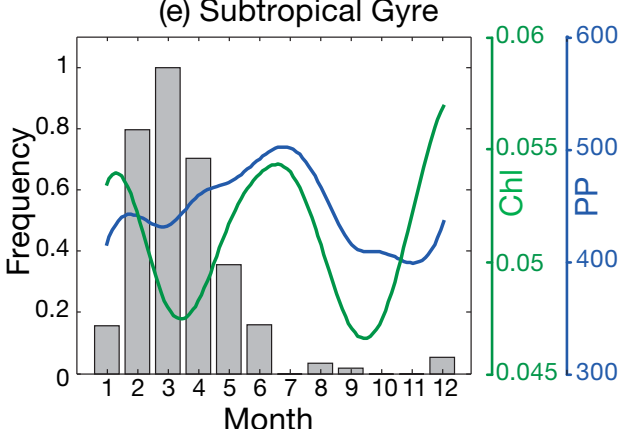

(c) Transition Zone

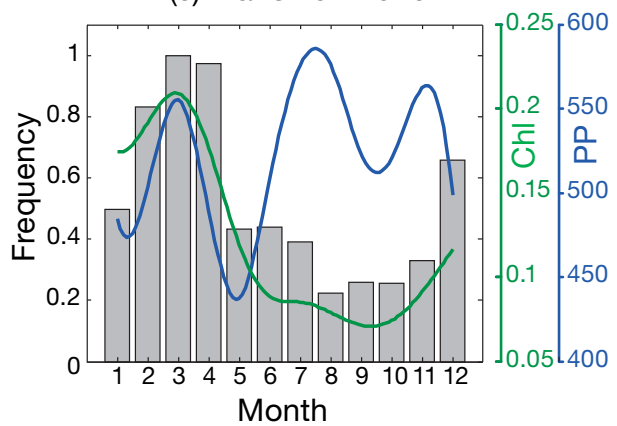

Fig. 5. Lamna ditropis. Seasonality of utilization (bars) of the major ecoregions of the eastern North Pacific Ocean by salmon sharks $(\mathrm{n}=68)$ compared to monthly median chlorophyll a (chl) concentration in log $\mathrm{mg} \mathrm{m}^{-3}$ (green) and primary production (PP) in $\mathrm{mg} \mathrm{C} \mathrm{m}^{-2} \mathrm{~d}^{-1}$ (blue). Ecoregions are (a) Coastal Alaska Downwelling Region, (b) Subarctic Alaska Gyre, (c) Transition Zone, (d) California Current Upwelling Region, and (e) Subtropical Gyre 
are able cross the entire Pacific to take advantage of the rich resources of the California Current before returning to the western North Pacific as adults (Bayliff et al. 1991). The number of bluefin that make this crossing appears to be related to the abundance of forage resources near Japan (Polovina 1996). The white shark Carcharodon carcharias makes long distance seasonal migrations between the coast of California and a region of the Subtropical Gyre midway between Baja California and Hawaii, though the life history functions of this migration are as yet unknown (Weng et al. 2007). The lamnid sharks and tunas, though related only in the very distant geological past, both share a suite of adaptations to endothermy that increase the power of their muscles (Bernal et al. 2005) and may enable them to undertake these long migrations (Weng et al. 2005).

\section{Ecological function of migration}

Salmon sharks appear to give birth during their southern migration in late spring-early summer. This timing is consistent with that in the western Pacific, where mating occurs during autumn and parturition in summer (Nagasawa 1998), and with an observation of a pregnant female in Alaska waters during December (Gallucci et al. 2008). Both males and females occur in Alaska waters during autumn (Hulbert et al. 2005), and fresh bite marks have been observed on females during this season, suggesting recent mating events (Goldman \& Human 2005). Due to the sexual segregation of salmon sharks in the north Pacific (Nagasawa 1998), mating on the southern migration would likely require that males undertake a long movement from the western North Pacific to the subtropical eastern North Pacific. This distance would exceed the movements undertaken by the females.

Parturition in the California Current region during spring is consistent with observations of young-of-theyear salmon sharks along the coast of California during spring (Goldman \& Human 2005). Parturition in the Subtropical Gyre is consistent with the occurrence of juvenile salmon sharks across a band of the Transition Zone (Nakano \& Nagasawa 1996). If parturition occurs in the Subtropical Gyre, neonates presumably swim north into the Transition Zone nursery as they grow.

The stock structure of salmon sharks is not known (Goldman \& Human 2005). There are differences in age and growth between western and eastern Pacific salmon sharks (Goldman \& Musick 2006), but these could occur due to either stock structure or differences in ecology. Our results show fidelity to a particular region over multiple years during the southern migration. If mating occurs in the south, these results indi- cate the possibility of separate stocks, though observations of bite marks on females suggest that mating occurs in the north. Genetic studies are needed to determine the population structure of salmon sharks.

The California Current appears to be a foraging region in addition to a parturition ground. ARS behaviors and long residency suggest that sharks forage successfully here. In contrast, the Subtropical Gyre may be predominantly a parturition ground, as sharks show fewer ARS behaviors, have shorter residency, migrate back north sooner and have longer northern residency. Some sharks that migrate to the Subtropical Gyre turn around and immediately begin migrating back toward the north, consistent with having given birth and having no other functions to fulfill in the region. Sharks that spend longer durations in the subtropical gyre may be waiting for their embryos to reach full term.

\section{Environmental factors mediating habitat selection}

Our research indicates that salmon shark behavior is mediated by the productivity of ecoregions. Derived metrics of salmon shark foraging activity - low speed, low straightness and high FPT - indicated that foraging occurs predominantly in the most productive ecoregions, the Coastal Alaska Downwelling and California Current regions. The kernel density method also highlights these 2 ecoregions as focal areas.

The behavior of salmon sharks was correlated with chl $a$ and PP. We do not suggest that behavior is directly mediated by chl a or PP. Studies of other pelagic vertebrates show mixed results with respect to orientation to satellite-measured mesoscale features (Hays et al. 2001b, Pinaud \& Weimerskirch 2005), but there is general support for the orientation of consumers to regions of higher productivity (Stephens \& Krebs 1986, Sims et al. 2003). Salmon sharks are likely to encounter higher prey densities in the most productive ecoregions, and thus modify their behavior.

Migration phenology did not correlate with seasonality of chl $a$ and PP. The upper trophic level at which salmon sharks feed means that a time lag occurs between productivity and the growth of forage resources. In addition, salmon sharks cannot be in all places all the time, so they may forgo the peak season in one region if the benefit of being in another region at that time is greater.

Salmon sharks did not appear to respond to temperature, and the ecological functions of migration, therefore, appear not to include the maintenance of an optimal thermal window. None of the 3 behavioral indices showed high correlations with temperature. Sharks initiated southern movements before and after the onset of winter in their coastal Alaska habitat, and in 
some cases skipped the southern migration entirely. The species is highly eurythermal (Goldman et al. 2004, Weng et al. 2005) and, therefore, can take advantage of foraging opportunities in a wide range of temperatures.

\section{Characteristics of ecoregions}

Salmon sharks spend the most time in the Coastal Alaska Downwelling region, which experiences downwelling and turbulent mixing, has strong seasonality of light, temperature and chl $a$ and the highest PP of any ecoregion in the eastern North Pacific (Longhurst 1998). The maximum summer-autumn utilization of the ecoregion coincides with the return of Pacific salmon Oncorhynchus spp. to their natal rivers to spawn. Salmon aggregate in coastal waters near the river mouths before embarking upon their upstream journeys, and during these staging periods are vulnerable to predation by salmon sharks (Hulbert \& Rice 2002). Salmon sharks are known to be major predators of salmon (Nagasawa 1998) and are frequently observed feeding on them in Alaska waters. The increase in their utilization of the ecoregion through the summer and autumn also follows the spring bloom and is consistent with the flow of energy up the food web into trophic levels occupied by herring Clupea pallasi, squid and demersal fishes, which salmon sharks feed on during these seasons (Hulbert et al. 2005).

During winter, the strength of the halocline prevents deep mixing in the coastal Alaska region, limiting the supply of nutrients to surface waters, and the short day length brings primary production to extremely low levels (Longhurst 1998). However, a variety of mid trophic level fishes remain in the region for the winter. Overwintering herring and walleye pollock Theragra chalcogramma aggregate in nearshore bays (Carlson 1980). These aggregated forage fishes may become vulnerable to salmon sharks, which maintain high body temperatures and activity patterns while in these cold waters (Goldman et al. 2004, Weng et al. 2005).

The California Current ecoregion had the second highest utilization by salmon sharks. The region is highly productive throughout the year as a result of the year-round availability of light at mid latitudes and the supply of nutrients to the photic zone as a result of waters entering the region from the West Wind Drift (Chelton et al. 1982) as well as strong wind-driven upwelling. Upwelling peaks during spring and summer, with a relaxation during autumn and occasional reversals during winter that are accompanied by a northward flow along the coast (Bolin \& Abbott 1963). Higher productivity occurs in the California Current system when upwelling is intermittent, with pauses in upwelling allowing nutrients to be utilized by phytoplankton before being advected offshore. As a result, productivity lags behind upwelling such that summer and autumn have the highest productivity (Bolin \& Abbott 1963).

The seasonality of salmon sharks and productivity do not correlate in the California Current. The time of highest productivity, late summer and autumn, is also the time of minimum utilization by salmon sharks, and vice versa during spring. This asynchrony may result from tradeoffs in the foraging ecology of salmon sharks, in which they forego the optimum season in the California Current because the benefit of being in the Coastal Alaska Downwelling region at that time is greater. Alternately, it may indicate that the targeted forage species in the California Current region do not themselves occur in synchrony with seasonal changes in productivity and that considerable time is required for PP to reach the trophic levels at which prey of salmon sharks occur (Frederiksen et al. 2006).

The California Current hosts a wide variety of teleost and elasmobranch fishes that are potential prey of salmon sharks (Hanan et al. 1993), and the timing of salmon shark utilization of the region corresponds to the life cycle of one of the most abundant prey species. The run timing of salmonids is closely tied to river water temperatures and flow regimes (Miller \& Brannon 1982). Whereas salmonids in Alaska and British Columbia (BC), Canada, typically undertake their upriver spawning runs once per year, during summer and fall, when temperatures are warmer and flows higher (Burger et al. 1985), many rivers south of Vancouver, $\mathrm{BC}$, have multiple runs per year or early runs (Myers et al. 1998). The precipitation regime of Oregon and California means that some headwater spawning habitats are typically accessible to large spawning fish only during spring peak river flows (Kostow 1995). The habitat suitability of the northern California Current region for salmon is broadest during spring and the animals inhabit a narrow thermal range (Hinke et al. 2005), potentially allowing the more eurythermal salmon sharks an advantage. In addition to the mature fish returning to the regions of their natal rivers, the spring season also sees the emigration of juvenile salmon from streams into the ocean, typically in their second or third year (Healey 1991), providing another potential food source for salmon sharks.

Salmon sharks showed few ARS behaviors in the Subarctic Alaska Gyre. The region is strongly influenced by high precipitation and, therefore, low surface salinity, causing a pycnocline that limits vertical mixing except during the stormy winter season, so productivity increases to high levels during spring and summer (Roden 1991). A wide variety of potential prey species exist in the region (Nelson 2003), but salmon 
sharks transited the region rapidly during both southward and northward migratory phases, indicating that the benefit of reaching their destination outweighed the benefits of foraging here (Dingle 1996).

Salmon sharks showed few ARS behaviors in the Transition Zone, which has moderate PP due to the availability of light at mid latitudes, combined with nutrient supply due to low stratification (Roden 1991, Longhurst 1998). The moderate productivity of the Transition Zone ecoregion makes it an important foraging region for a number of upper trophic level pelagic vertebrates including turtles (Polovina et al. 2000), pinnipeds (Le Boeuf et al. 2000), fishes (Laurs \& Lynn 1991) and squids (Pearcy 1991). The utilization of the Transition Zone by juvenile salmon sharks is known to be high (Nakano \& Nagasawa 1996), and they are found in association with a diverse guild of potential prey species (Pearcy 1991). The transiting behavior of mature salmon sharks in the Transition Zone suggests that they are likely to be targeting more distant regions for foraging or parturition.

The Subtropical Gyre is a large body of uniform water with low nutrient levels and productivity (Longhurst 1998) yet was a destination for salmon sharks. Residency was shorter here than in the California Current, suggesting that the region is less important for foraging, and highlighting the possibility of parturition. The low abundance of pelagic sharks in this oligotrophic region could offer predation release (Okamoto \& Bayliff 2003), but the low abundance of forage species (Murata 1990, Seki et al. 2002) would be a disadvantage. If parturition does occur in this region, it is likely that neonates move northward as they grow, since juveniles are abundant in the transition zone (Nagasawa 1998).

Measurements of animal movement and the environment can be used to construct quantitative behavioral indices that elucidate the ecological functions of migration and the partitioning of habitats. We demonstrate that an upper trophic level predator shows more restricted search behaviors where productivity is greater, and makes rapid directed migrations between the 2 most productive ecoregions of the eastern North Pacific. There is a need to further test hypotheses of ecological function through direct studies of behavior, foraging, parturition and genetic population structure. Understanding the biology of abundant, upper trophic level predators such as the salmon shark is essential to our understanding of the structure and function of ecosystems as a whole.

Acknowledgements. Funding was provided by the ONR, Sloan, Moore and Packard Foundation to B.A.B. We thank D. Branshaw of the Alaska Department of Fish and Game, P. Castilho, R. Shallert, J. Musick, C. Conrath, C. Farwell,
J. O'Sullivan, L. DeWitt, S. Bograd, D. Palacios, D. Costa, K. Goldman, A. Swithenbank, S. Teo, D. Kohrs, H. Dewar, A. Boustany, G. Strout, M. Castleton and R. Matteson. MatLab code for First Passage Time was provided by P. Robinson and A. Walli. ERDDAP was developed by B. Simons and R. Mendelssohn. The project was conceived by B.A.B. and K.C.W.; fieldwork was conducted by B.A.B., K.C.W., C.P., G.L.S. and others; data were analyzed by K.C.W., D.G.F. and J.E.G.; and the manuscript was written by K.C.W.

\section{LITERATURE CITED}

Batschelet E (1981) Circular statistics in biology. Academic Press, London

Bayliff W, Ishizuka Y, Deriso R (1991) Growth, movement, and attrition of northern bluefin tuna, Thunnus thynnus, in the Pacific Ocean, as determined by tagging. IATTC, La Jolla, CA

Behrenfeld MJ, Falkowski PG (1997) Photosynthetic rates derived from satellite-based chlorophyll concentration. Limnol Oceanogr 42:1-20

Bernal D, Donley JM, Shadwick RE, Syme DA (2005) Mammal-like muscles power swimming in a cold-water shark. Nature 437:1349-1352

Beyer HL (2004) Hawth's analysis tools for ArcGIS. Available at: www.spatialecology.com/htools

Bolin R, Abbott D (1963) Studies on the marine climate and phytoplankton of the central coastal area of California, 1954-1960. CCOFI Rep 9:23-45

Bradshaw CJA, Sims DW, Hays GC (2007) Measurement error causes scale-dependent threshold erosion of biological signals in animal movement data. Ecol Appl 17: $628-638$

Burger CV, Wilmot RL, Wangard DB (1985) Comparison of spawning areas and times fortwo runs of chinook salmon (Oncorhynchus tshawytscha) in the Kenai River, Alaska. Can J Fish Aquat Sci 42:693-700

Burt W (1943) Territoriality and home range concepts as applied to mammals. J Mammal 24:346-352

Carlson HR (1980) Seasonal distribution and environment of Pacific Herring near Auke Bay, Lynn Canal, Southeastern Alaska. Trans Am Fish Soc 109:71-78

Chelton D, Bernal P, Mcgowan J (1982) Large-scale inter annual physical and biological interaction in the California Current. J Mar Res 40:1095-1126

Dingle H (1996) Migration: the biology of life on the move. Oxford University Press, New York

Fauchald P, Tveraa T (2003) Using first-passage time in the analysis of area-restricted search and habitat selection. Ecology 84:282-288

Frederiksen M, Edwards M, Richardson AJ, Halliday NC, Wanless S (2006) From plankton to top predators: bottomup control of a marine food web across four trophic levels. J Anim Ecol 75:1259-1268

Gallucci VF, Foy RJ, O'Brien SM, Aires-Da-Silva A and others (2008) Information from a pregnant salmon shark Lamna ditropis in the eastern North Pacific with observations on oophagous reproduction. J Fish Biol 73:732-739

Gilmore R (1960) Census and migration of the California gray whale. Nor Hvalfangsttid 49:409-431

Goldman KJ, Human B (2005) Salmon shark, Lamna ditropis. In: Fowler SL, Camhi M, Burgess GH, Cailliet GM and others (eds) Sharks, rays and chimaeras: the status of the chondrichthyan fishes. IUCN SSC Shark Specialist Group. IUCN, Gland and Cambridge 
Goldman KJ, Musick JA (2006) Growth and maturity of salmon sharks in the eastern and western North Pacific, and comments on back-calculation methods. Fish Bull (Wash DC) 104:278-292

Goldman KJ, Musick JA (2008) Biology and ecology of the salmon shark, Lamna ditropis. In: Pikitch EK, Camhi M (eds) Sharks of the open ocean. Blackwell Scientific, Maldon, MA

Goldman K, Anderson S, Latour R, Musick J (2004) Homethermy in adult salmon sharks, Lamna ditropis. Environ Biol Fishes 71:403-411

Hanan DA, Holts DB, Coan AL Jr (1993) The California drift gill net fishery for sharks and swordfish, 1981-82 through 1990-91. Calif Dep Fish Game Fish Bull 175

Hays GC, Akesson S, Godley BJ, Luschi P, Santidrian P (2001a) The implications of location accuracy for the interpretation of satellite-tracking data. Anim Behav 61:1035-1040

Hays GC, Dray M, Quaife T, Smyth TJ and others (2001b) Movements of migrating green turtles in relation to AVHRR derived sea surface temperature. Int J Remote Sens 22:1403-1411

Healey MC (1991) The life history of chinook salmon (Oncorhynchus tshawytscha). In: Groot C, Margolis L (eds) Life history of Pacific salmon. University of British Columbia Press, Vancouver, BC, p 311-393

Hill S, Burrows MT, Hughes RN (2000) Increased turning per unit distance as an area-restricted search mechanism in a pause-travel predator, juvenile plaice, foraging for buried bivalves. J Fish Biol 56:1497-1508

Hinke JT, Watters GM, Boehlert GW, Zedonis P (2005) Ocean habitat use in autumn by Chinook salmon in coastal waters of Oregon and California. Mar Ecol Prog Ser 285:181-192

Hooge PN, Eichenlaub B (1997) Animal movement extension to ArcView. Alaska Science Center-Biological Science Office, US Geological Survey, Anchorage, AK,

Hubbs CL, Follett WI (1947) Lamna ditropis, new species, the salmon shark of the North Pacific. Copeia 1947:194

Hulbert L, Rice S (2002) Salmon shark, Lamna ditropis, movements, diet, and abundance in the Eastern North Pacific Ocean and Prince William Sound, Alaska. Exxon Valdez Oil Spill Restoration Project 02396 Final Report. NOAA Fisheries, Juneau, AK

Hulbert L, Aires-Da-Silva AM, Gallucci VF, Rice JS (2005) Seasonal foraging movements and migratory patterns of female Lamna ditropis tagged in Prince William Sound, Alaska. J Fish Biol 67:490-509

Hunter MD, Price PW (1992) Playing chutes and ladders: heterogeneity and the relative roles of bottom-up and topdown forces in natural communities. Ecology 73:724-732

Kareiva P, Odell G (1987) Swarms of predators exhibit prey taxis if individual predators use area-restricted search. Am Nat 130:233-270

Kostow K (1995) Biennial report on the status of wild fish in Oregon. Oregon Department of Fish and Wildlife, Portland, OR

Laurs RM, Lynn RJ (1991) North Pacific albacore ecology and oceanography. In: Wetherall JA (ed) Biology, oceanography and fisheries of the North Pacific Transition Zone and Subarctic Frontal Zone. NOAA Tech Rep NMFS 105: 69-87

Le Boeuf BJ, Laws R (1994) Elephant seals: an introduction to the genus. In: Le Boeuf BJ, Laws R (eds) Elephant seals: population ecology, behavior, and physiology. University of California Press, Berkeley, CA, p 1-28

Le Boeuf BJ, Crocker DE, Costa DP, Blackwell SB, Webb PM, Houser DS (2000) Foraging ecology of northern elephant seals. Ecol Monogr 70:353-382
Longhurst AR (1998) Ecological geography of the sea. Academic Press, San Diego, CA

Miller RJ, Brannon EL (1982) The origin and development of life-history patterns in Pacific salmon. In: Brannon EL, Salo EO (eds) Proceedings of the Salmon and Trout Migratory Behavior Symposium. University of Washington Press, Seattle, WA, p 296-309

Murata M (1990) Oceanic resources of squids. Mar Behav Physiol 18:19-71

Myers JM, Kope RG, Bryant GJ, Teel D and others (1998) Status review of chinook salmon from Washington, Idaho, Oregon, and California. NOAA Tech Memo NMFSNWFSC-35

Nagasawa K (1998) Predation by salmon sharks (Lamna ditropis) on Pacific salmon (Oncorhynchus spp.) in the North Pacific Ocean. North Pac Anadromous Fish Comm Bull 1998:419-433

Nakano H, Nagasawa K (1996) Distribution of pelagic elasmobranchs caught by salmon research gillnets in the North Pacific. Fish Sci 62:860-865

Nelson M (2003) NPFMC Gulf of Alaska SAFE: forage fish species in the Gulf of Alaska (Appendix A). North Pacific Fishery Management Council, Anchorage, AK

Nolet BA, Mooij WM (2002) Search paths of swans foraging on spatially autocorrelated tubers. J Anim Ecol 71:451-462

Okamoto H, Bayliff WH (2003) A review of the Japanese longline fishery for tunas and billfishes in the eastern Pacific Ocean, 1993-1997. Inter-Am Trop Tuna Comm Bull 22: 221-431

Okey T, Pauly D (1999) A trophic mass-balance model of Alaska's Prince William Sound ecosystem for the post-spill period 1994-1996. Fisheries Centre Research Reports 7, University of British Columbia, Vancover, BC

Pawlowicz R (2006) M_Map: a mapping package for Matlab. Available at: www.eos.ubc.ca/ rich/map.html

Pearcy WG (1991) Biology of the Transition Region. In: Weatherall J (ed) Biology, oceanography, and fisheries of the North Pacific Transition Zone and Subarctic Frontal Zone. NOAA Tech Rep NMFS 105:1-38

Pinaud D, Weimerskirch H (2005) Scale-dependent habitat use in a long-ranging central place predator. J Anim Ecol 74:852-863

Polovina J (1996) Decadal variation in the trans-Pacific migration of northern bluefin tuna (Thunnus thynnus) coherent with climate-induced change in prey abundance. Fish Oceanogr 5:114-119

Polovina JJ, Kobayashi DR, Parker DM, Seki MP, Balazs GH (2000) Turtles on the edge: movement of loggerhead turtles (Caretta caretta) along oceanic fronts, spanning longline fishing grounds in the central North Pacific, 19971998. Fish Oceanogr 9:71-82

> Robinson PW, Tremblay Y, Crocker DE, Kappes MA and others (2007) A comparison of indirect measures of feeding behaviour based on ARGOS tracking data. Deep-Sea Res II 54:356-368

Roden G (1991) Subarctic-subtropical transition zone of the North Pacific: large-scale aspects and mesoscale structure. In: Wetherall J (ed) Biology, oceanography, and fisheries of the North Pacific Transition Zone and Subarctic Frontal Zone. NOAA Tech Rep NMFS 105:1-38

Seki MP, Polovina JJ, Kobayashi DR, Bidigare RR, Mitchum GT (2002) An oceanographic characterization of swordfish (Xiphias gladius) longline fishing grounds in the springtime subtropical North Pacific. Fish Oceanogr 11:251-266

Serventy D (1967) Aspects of the population ecology of the shorttailed shearwater. Proceedings XIV International Ornithological Congress, Oxford, p 165-190 
Sims DW, Southall EJ, Richardson AJ, Reid PC, Metcalfe JD (2003) Seasonal movements and behaviour of basking sharks from archival tagging: no evidence of winter hibernation. Mar Ecol Prog Ser 248:187-196

Spotila JR (2004) Sea turtles: a complete guide to their biology, behavior, and conservation. Johns Hopkins University Press, Baltimore, MD

Stephens DW, Krebs JR (1986) Foraging theory. Princeton University Press, Princeton, NJ

Sundstrom LF, Gruber SH, Clermont SM, Correia JPS and others (2001) Review of elasmobranch behavioral studies using ultrasonic telemetry with special reference to the lemon shark, Negaprion brevirostris, around Bimini Islands, Bahamas. Environ Biol Fishes 60:225-250

Teo SLH, Boustany A, Dewar H, Stokesbury MJW and others (2007) Annual migrations, diving behavior, and thermal biology of Atlantic bluefin tuna, Thunnus thynnus, on

Editorial responsibility: Rory Wilson,

Swansea, UK their Gulf of Mexico breeding grounds. Mar Biol 151:1-18 Tremblay Y, Shaffer SA, Fowler SL, Kuhn CE and others (2006) Interpolation of animal tracking data in a fluid environment. J Exp Biol 209:128-140

Weng KC, Castilho PC, Morrissette JM, Landiera-Fernandez A and others (2005) Satellite tagging and cardiac physiology reveal niche expansion in salmon sharks. Science 310: 104-106

> Weng K, Boustany A, Pyle P, Anderson S, Brown A, Block B (2007) Migration and habitat of white sharks (Carcharodon carcharias) in the Eastern Pacific Ocean. Mar Biol 152: 877-894

White NA, Sjoberg M (2002) Accuracy of satellite positions from free-ranging grey seals using ARGOS. Polar Biol 25: 629-631

Worton BJ (1989) Kernel methods for estimating the utilization distribution in home-range studies. Ecology 70:164-168

Submitted: June 11, 2008; Accepted: August 22, 2008

Proofs received from author(s): November 18, 2008 